\title{
Using Evolution as the Framework for Teaching Biology
}

\author{
David L. Alles \\ Western Washington University \\ e-mail: alles@biol.wwu.edu
}

Alles, D. L. (2001). Using Evolution as the Framework for Teaching Biology. The American Biology Teacher, Vol. 63, No. 1(January), 20-23.

\section{Introduction}

In April of 1998, the National Academy of Sciences published the booklet Teaching about Evolution and the Nature of Science (NAS, 1998). The booklet challenges teachers to use evolution as the organizing theme in teaching biology, rather than treating evolution as a separate topic. The NAS also emphasizes the importance of teaching biology students the nature of science. These recommendations are admirable, but their acceptance so far has been limited. In this article I report on my efforts to teach the nature of science and to use evolution as the framework for teaching biology.

Since the Fall of 1997, I have been teaching a non-major's general biology course, Biology 101, at Western Washington University in Bellingham, Washington. I have now taught the course eight times to a combined total of over seven hundred students. The course is experimental in that it does not follow the traditional scope and sequence for teaching biology, as exemplified by the majority of current textbooks for a non-major's general biology course. The major changes that I have made are 1) evolution and the history of life are used as the curriculum framework and 2) an extensive unit has been added on the history and philosophy of science. Although the design of the course predates the publication of the NAS booklet, the curriculum changes I have made follow the NAS's central recommendations. As a result, my experience teaching this course represents an unintended test case for the NAS recommendations on teaching evolution and the nature of science.

\section{From Evolutionary Theory to the History of Life}

Why has the National Academy of Sciences recommended that evolution be the conceptual framework for teaching biology? The recommendation follows from understanding that curriculum development in science education should be based on the synthesis inherent in scientific paradigms. Scientific paradigms are scientific theories that unite an entire field of scientific study, such as evolution by natural selection in biology and plate tectonics in geology. The practical problem is how to use such theories as the framework for a science curriculum. The first step in solving this problem for biology is recognizing that the history of life on Earth contains the explanation for the origin of every aspect of the living world today. 
In addition, by using a narrative presentation of the history of life, we automatically set evolution as the framework for teaching biology. In presenting biological knowledge in the chronological framework of the history of life, the explanatory power of evolution is matched to the presentation that best utilizes that power to integrate scientific knowledge into a coherent picture of the natural world.

\section{Teaching the Nature of Science}

Why has the NAS also emphasized the importance of teaching the nature of science? Approximately 35\% of American adults accept a literal interpretation of the Bible (including the story of creation and the age of the Earth), and approximately $68 \%$ of Americans think creationism should be taught along with evolution in public schools (Holden, 1999). The lesson from this is that we must change how we teach biology. We must recognize that science does not have unquestioned credibility with the American public, and as a result, we must demonstrate why science is credible. To accomplish this, we must integrate the history and philosophy of science into the biology curriculum.

Fortunately, excellent resources exist for incorporating these elements into a science curriculum. Chapter Three of the NAS booklet is devoted to explaining the nature of science. In addition, I recommend two recent books on the nature of biology, Ernst Mayr's This is Biology (1997) and Michael Ruse's Mystery of Mysteries: Is Evolution a Social Construct? (1999). Ernst Mayr's This is Biology is a readily accessible overview of the history and philosophy of biology written for the general public. In some respects, This is Biology is a popular version of Mayr's monumental work The Growth of Biological Thought (1982). Mystery of Mysteries is a popular, and very accessible, version of the ideas Ruse first presented in his 1996, book Monad to Man: The Concept of Progress in Evolutionary Biology (1996). In Chapter One of Mystery of Mysteries Ruse provides an excellent summary of the recent history of the philosophy of science by contrasting the philosophies of Sir Karl Popper and Thomas Kuhn. In the same chapter he provides a summary of the epistemological values of science. I have adopted his summary of epistemic values, with some modifications, for use in my course. The balance of Ruse's book is devoted to biographic portraits of some of the most important scientists in the history of evolutionary biology, from Erasmus Darwin (Charles Darwin's grandfather), to Theodosius Dobzhansky, Richard Dawkins, Stephen Jay Gould, and E. O. Wilson to name a few. The works of both Mayr and Ruse are cited in Teaching about Evolution and the Nature of Science (NAS, 1998), as references for further reading.

\section{The Course}

The course I have been teaching lasts ten weeks (one quarter) with 28 lectures. Class size is typically 100 students. The content of the course is divided into four parts presented in the order listed below. 


\section{The Nature of Science}

2. The Conceptual Framework of Biology

3. The Integration of Biological Knowledge and the History of Life

4. Biology and Society

\section{The Nature of Science}

Part One, The Nature of Science, contains three primary topics devoted to defining what science is: the epistemological values of science, the origin of modern science, and science as a profession. Presenting the nature of science at the beginning of a non-majors biology course allows for the presentation of the epistemological issues that surround the teaching of evolution, namely the nature of acceptable evidence. By showing our students the contrast between what is acceptable evidence in science as opposed to what is acceptable evidence in theistic religions, namely divine revelation and the word of authority, we can set the stage for a non-confrontational presentation of evolutionary theory. Presenting the origin of modern science serves to show when the rejection of the word of authority that led to modern science first began. Portraying how science operates as a profession shows how this epistemic value is maintained. This method of defining science focuses attention on the commitment of science to using only physical evidence in trying to understand the natural world. This does not mean, however, that we must directly observe every event in the natural world to understand it scientifically. Historical sciences, such as biology and geology, depend on logical inference, technically known as "retroduction" (McMullin, 1988), from physical evidence in the present to scientific conclusions about the past. As biology teachers we must understand that it is the total reliance upon physical evidence for testing hypotheses and making logical inferences that makes scientific knowledge the most credible knowledge we have of the natural world.

\section{The Conceptual Framework of Biology}

Part Two, The Conceptual Framework of Biology, includes cosmological evolution, natural levels of organization in the physical world, biological evolution, life as a chemical function (biochemistry and genetics), and the modern synthesis (Darwin and Mendel). This section of the course is devoted to explaining the process of evolution by natural selection and the genetic basis by which natural selection operates. To do so, it is necessary to show the fundamental causal mechanisms that lead to evolutionary change. Cosmological evolution, as a broader view of evolutionary change, provides the opportunity to explain the causal relationships behind evolution not only in biological systems but in the universe as a whole. For a lucid introduction to this topic see Jacob Bronowski's essay New Concepts in the Evolution of Complexity (1977). Excellent popular books on cosmological evolution include Timothy Ferris' books Coming of age 
in the Milky Way (1988) and The Whole Shebang (1997), which contain a wealth of accessible information and ideas on both the evolution of the universe and life on Earth.

My presentation of the theory of evolution by natural selection is based on the analysis presented by Ernst Mayr in his book The Growth of Biological Thought (1982, 505). Mayr concludes that Darwin had five separate theories, each addressing a different aspect of evolution. My presentation of biochemistry and genetics is traditional. The emphasis is on how the molecular nature of DNA and the process of meiosis provide the variation and genetic mixing that are the raw material for natural selection. The final topic of Part Two brings classical genetics together with evolutionary theory by presenting the modern synthesis of biology, a topic also well covered by Mayr (1982). Presenting the conceptual background of evolution in this manner before beginning the history of life, allows a natural transition to the origin of life on Earth and its subsequent history.

\section{The Integration of Biological Knowledge}

Part Three, The Integration of Biological Knowledge and The History of Life, is the longest portion of the course and includes the following topics: geologic time, the origin of life, photosynthesis, aerobic respiration, endosymbiosis and eukaryotic cells, sexual reproduction, multicellularity, adaptive radiations and mass extinctions, vertebrate evolution, and human evolution. In presenting the history of life on Earth, I have changed the emphasis from the traditional concentration on the Phanerozoic Eon in favor of the more fundamental events of the Precambrian. This allows me to concentrate on prokaryotic evolution including such milestones as the evolution of photosynthesis, aerobic respiration, and the endosymbiotic evolution of eukaryotic cells. Following these topics, I present the evolution of sexual cellular reproduction and the evolution of multicellularity in eukaryotes. This sequence emphasizes the major features of all of life on Earth today and explains the basis for classifying life into six kingdoms: bacteria, archaea, protists, plants, fungi, and animals. At each of the major events in the history of life, such as the evolution of photosynthesis and aerobic respiration, I bring the subject to the present and relate it to living organisms and their interactions as a part of an ecological whole. By doing so I am able to tie an understanding of the evolution of life on earth to an understanding of the intimate relationships of the living world today.

After this concentration on Precambrian evolution, I continue on to the evolution of vertebrates in the Phanerozoic. Mass extinction events and adaptive radiations are an intregal part of this story. Presenting our knowledge of these events also sets the stage for discussing biodiversity in the final portion of the course. The length of the course prevents me from doing a complete survey of invertebrate and plant evolution, but the emphasis on vertebrate evolution has the side benefit of relating the material directly to the students. I follow this emphasis through to the evolution of primates and on to human evolution, always relating each step to explaining how we came to be the way we are today. 
All the topics in Part Three are presented in chronological order as a narrative of the evolutionary history of life on Earth. Admittedly, given only ten weeks to teach, it is necessarily an incomplete history. There is, however, a silver lining to the short length of the course. Because of the scope of the topics covered, the course can be easily expanded from ten weeks to a semester or full academic year. As the title of Part Three, The Integration of Biological Knowledge, announces, the scope and nature of the history of life on Earth also lends itself to the integration of all scientific knowledge.

\section{Biology \& Society}

The last part of the course, Biology and Society, is the shortest and contains the topics science and ethics, human population growth, and "the Sixth Extinction" (Wilson, 1992). Part Four brings the major trends in the history of life to the present by addressing some of the major questions of our times. How does scientific knowledge affect social, ethical questions? How has science changed our world? What is the status of biodiversity today, and what role does humanity play in it? By asking these questions we can show the connections between the growth of the human population and the loss of biodiversity. And finally, we can pose the question of what our ethical responsibilities are in this, the sixth, and potentially the worst, mass extinction event in the history of life on Earth.

\section{Textbooks \& Lecture Notes}

To the best of my knowledge, there are currently no textbooks on the market that follow the scope and sequence I have used in my non-major's course in biology. There are currently, also, no textbooks that support the NAS's recommendations on teaching evolution and the nature of science. For these reasons, I have published my lecture notes as a required text for my course. Based on student comments and written evaluations, the lecture notes have been readily accepted by my students as a substitute for a textbook. There are, however, a small number of popular books that could be used as a text for the history of life, such as The Book of Life edited by Stephen Jay Gould (1993) or A Walk Through Time: From Stardust to Us by Liebes, Sahtouris, and Swimme (1998).

\section{Testing \& Evaluating Students}

Teaching at least a hundred students at a time places severe limitations on the methods of student evaluation. In spite of this, I have allocated the resources, mainly time, to giving four essay quizzes during the course. The essay format allows me to ask conceptual questions about the course content. In addition to four essay quizzes, there is a midterm and final exam. I have held the line against multiple-choice questions by asking only short answer questions on these tests. An additional limitation on teaching such large classes is on any form of class discussion. Given the nature of the material cover in my course, this is unfortunate, as the material lends itself to class discussions. 


\section{Course Evaluations}

Biology 101 at Western is a non-major's general education requirement for graduation. In spite of pervasive apathy toward such courses, the results of this innovative version of Biology 101, based on student evaluations and student performance, are positive.

On a 1 to 5 scale running from very poor to excellent the course has been consistently rated from good (3) to very good (4) with an over-all average evaluation of 3.85. Surprisingly, the intellectual challenge offered by the course has, as consistently, been rated higher with an average of 4.00 .

The course has maintained a reasonable amount of rigor with an over-all class average of $79 \%$ and a median of $80 \%(\mathrm{n}=696)$. As a measure of grade inflation (or lack thereof), $16 \%$ of the students earned a grade of $\mathrm{A}-$ to $\mathrm{A}$. By comparison the national average in higher education is approximately $26 \%$ today and was $19 \%$ in 1976 (Comarow, 1999). Even so, it has been fairly easy to pass the course; an average of $93 \%$ of those who enrolled have passed $(n=720)$.

In addition, hundreds of written evaluations have been provided by students. The vast majority of these evaluations, although not all, are positive.

One, however, stands out:

\section{"Professor Alles,}

Thank you so much for this course. I had such a good time in your class. I had been dreading taking a science class, but I found that this class was the one I most looked forward to. It is so refreshing to see material presented in a way that is not laced with "factoids" (as you called them), but real things that pertain to more than just daily life, but our very existence. I read somewhere that when you learn something it feels at first as though you have lost something. I do not mourn the things I have lost from what I've learned in your class. How refreshing to walk out of the room actually feeling lighter because you have left old assumptions, naive perceptions and traditions in a pile at your feet."

Anonymous student evaluation

In spite of past attempts to survey student's beliefs on evolution (which have proven to be too intrusive), it is unknown how closely the student body at WWU reflects the beliefs and attitudes of the America public toward evolution. Undeniably, there have been a number of students in each of the classes I have taught that have had strong feelings against evolution. (They have made themselves known.) It is, therefore, gratifying to have a positive outcome to a course that has been unambiguous about the importance of evolution. Whether or not I have changed any of my students view of the world is another question. And yet, equally undeniable, based on written student 
evaluations, is that I have shown some of my students the importance of scientific knowledge to their lives.

\section{Conclusion}

The take-home message from this experimental biology course is that a natural sequence to teaching the topics of biology exists and from this sequence flows our understanding of the natural world. This insight, however, is useless if we do not at the same time make our students aware of the nature of science. This is the message of the National Academy of Sciences, and my experience has shown that, it is not only possible to use evolution as the framework for teaching biology, it is what we should do if understanding the natural world and ourselves is the goal of teaching biology.

(For further information about this course, complete lecture notes and references are available on-line at: http://fire.biol.wwu.edu/trent/alles/ )

\section{References}

Bronowski, J. (1977). A Sense of the Future. Cambridge, MA: The MIT Press.

Comarow, A. (1999). Grades are up, and standards are down. (in) U.S. News \& World Report's Americas Best Colleges, 1999.

Ferris, T. (1988). Coming of Age in the Milky Way. New York: William Morrow.

Ferris, T. (1997). The Whole Shebang. New York: Simon \& Schuster.

Gould (ed.), S. J. (1993). The Book of Life. New York: Norton.

Holden, C. (1999). Breakdown of the Year: Creationists Win in Kansas. Science, 286(Dec.17), 2242.

Liebes, S., Sahtouris, E., \& Swimme, B. (1998). A Walk Through Time: From Stardust to Us. New York: Wiley.

Mayr, E. (1982). The Growth of Biological Thought: Diversity, Evolution, and Inheritance. Cambridge, MA: Belnap Press of Harvard University Press.

Mayr, E. (1997). This is Biology. Cambridge, MA: Belnap Press of Harvard University Press. 
McMullin, E. (ed.) (1988). Construction and Constraint: The Shaping of Scientific Rationality. Notre Dame, Ind.: University of Notre Dame Press.

National Academy of the Sciences (1998). Teaching about Evolution and the Nature of

Science. Washington D.C.: National Academy Press. (To order a copy of this booklet call 1800-624-6242 or contact the National Academy Press on-line at:

http://www.nap.edu/readingroom/books/evolution98 .)

Ruse, M. (1996). Monad to Man: The concept of Progress in Evolutionary Biology. Cambridge, MA: Harvard University Press.

Ruse, M. (1999). Mystery of Mysteries: Is Evolution a Social Construct? Cambridge, MA: Harvard University Press.

Wilson, E. O. (1992). The Diversity of Life. Cambridge, MA: Belnap Press of Harvard University Press.

\author{
For other papers by David L. Alles go to: \\ http://fire.biol.wwu.edu/trent/alles/papersindex.html
}

For David L. Alles Biology Home Page go to:

http://fire.biol.wwu.edu/trent/alles/index.html 